\begin{tabular}{|c|c|c|c|c|c|c|c|}
\hline 云木 & 康雄 & 宮崎 & 光一 & 石須 & 良一 & 中西 & 歩 \\
\hline 牧野 & 幸郎 & 清水 & 敦哉 & 野口 & 幸延 & 田川 & 新生 \\
\hline 村田 & 佐門* & 伊藤 & 信康 & 高瀬 & 次郎 & 中野 & 趃** \\
\hline 為田 & 勤彦 & 小坂 & 義種" & & & & \\
\hline
\end{tabular}

要 旨：1988年以降当院において経験した若年者（15～23歳）発症の麻疹症例のらち，入院を 要した 8 例につき，主に肝障害に関して臨床病理学的検討を行った，GOT，GPT，LDHの上 升は全例に認めたが，黄㡺を認めた例はなかった。血清 GPT 值は発疹出現とともに上昇し，6 〜 7 日後に最高値をとり, 以後程過とともに正常化した。血清 LDHは発疹出現時より上昇し, GPT より 2 - 3 日早く最高値をとる傾向がみられ，約 2 週間で正常化した. 8 例中 6 例で回復 期に肝生検を行った．組織学的には全例に軽度の肝細胞壊死を認めたが，グリンン鞘域の変化 はほとんど認めなかった。

索引用語：麻疹 肝障害 肝生検

\section{緒言}

麻到の合併症としての肝障害は、これまであまり注 目されることがなく，本邦における報告は少ない，麻 疹患者における肝機能異常の出現頻度は, Gavish ら” は65例 中 52 例 $(80 \%)$, Mouallem 5 2) は40例 中 28 例 $70 \%$ ，矢木ら ${ }^{3)}$ は 10 例中 4 例 $(40 \%)$ と報告し，これ まで考えられていたほど稀ではないよらである。その 重症度については、軽铛のものからトランスフミナー ゼか500IU 前後と高値を示するのまで多彩である。 一
方，麻疹患者の中にはGPT の上昇に比L GOT, LDH の上昇が著明な例があり，逸脱酵素の上昇は肝細胞以 外の臓器に由来するという報告る見られる ${ }^{7,8)}$ 。そこで 著者らは，1988年以降当院において経験した成人発症 の麻疹症例のうち，入院を要した 8 例について臨床像 を検討するととるに，共存する胢機能異常の特徽像を 明らかにすることを試みた。

\section{対象と結果}

対象は, 男 2 名, 女 6 名であり，年齢は 15 歳から 23

Table 1 Clinical and laboratory findings of 8 patients on admission and anti measles antibody.

\begin{tabular}{|c|c|c|c|c|c|c|c|c|}
\hline \multirow{2}{*}{$\begin{array}{l}\text { Case } \\
\text { No }\end{array}$} & \multirow{2}{*}{$\begin{array}{l}\text { Age } \\
\text { (y/o) } \\
\text { /Sex }\end{array}$} & \multicolumn{2}{|c|}{ Duration 'day's } & \multirow{2}{*}{$\begin{array}{c}\mathrm{WBC} \\
\left(/ \mathrm{mm}^{3}\right)\end{array}$} & \multirow{2}{*}{$\begin{array}{l}\text { Neu. } \\
0 \%\end{array}$} & \multirow{2}{*}{$\begin{array}{l}\text { Lym. } \\
(\%)\end{array}$} & \multirow{2}{*}{$\begin{array}{l}\text { Eosi. } \\
(\%)\end{array}$} & \multirow{2}{*}{$\begin{array}{c}\text { Anti-Measles } \\
\text { antibody }\end{array}$} \\
\hline & & Fever & Rash & & & & & \\
\hline 1 & $21 / F$ & 7 & 4 & 3.800 & 66 & 24 & 5 & $\operatorname{Ig} M(+) \operatorname{EIA}$ \\
\hline 2 & $21 / F$ & 8 & 4 & 6.500 & 79 & 9 & 2 & $\operatorname{IgM}(+)(\mathrm{EIA})$ \\
\hline 3 & $16 / F$ & 7 & 4 & 5.700 & 18 & 58 & 4 & $\operatorname{Ig} M(+)(E I A)$ \\
\hline 4 & $16 / F$ & 10 & 6 & 3.000 & 89 & 2 & 0 & $\operatorname{IgM}(+) \operatorname{EIA}$ \\
\hline 5 & $23 / F$ & 10 & 8 & 3.300 & 72 & 25 & 0 & $\operatorname{Ig} M(+)(E I A)$ \\
\hline 6 & $15 / F$ & 8 & 4 & 4,600 & 70 & 20 & 2 & $\times 16 \rightarrow 256(\mathrm{HI})$ \\
\hline 7 & $16 / \mathrm{M}$ & 9 & 5 & 3,100 & 74 & 13 & 2 & $\lg M(+)(E I A)$ \\
\hline 8 & $23 / \mathrm{M}$ & 9 & 5 & 8.800 & 76 & 21 & 0 & $\operatorname{IgM}(+)(\mathrm{EIA})$ \\
\hline
\end{tabular}

* 三重祡立志摩病院内科

**三重大学医学部第 1 内科

*** 三重大学医学部唡查医学 
Table 2 Maximum values of liver function tests in 8 patients with measles.

\begin{tabular}{c|c|c|c|c|c|c}
\hline $\begin{array}{c}\text { Case } \\
\text { No }\end{array}$ & $\begin{array}{c}\text { T-Bil } \\
(0.3 \sim \operatorname{lmg} / \mathrm{d} l)\end{array}$ & $\begin{array}{c}\text { GOT } \\
(5 \sim 35 \mathrm{IU})\end{array}$ & $\begin{array}{c}\text { GPT } \\
(0 \sim 30 \mathrm{IU})\end{array}$ & $\begin{array}{c}\text { LDH } \\
(50 \sim 200 \mathrm{IU})\end{array}$ & $\begin{array}{c}\text { Al-P } \\
(30 \sim 100 \mathrm{IU})\end{array}$ & $\begin{array}{c}\gamma \cdot \mathrm{GTP} \\
(11 \sim 60 \mathrm{IU})\end{array}$ \\
\hline 1 & 0.51 & 106 & 109 & 349 & 47 & 30 \\
2 & 0.59 & 101 & 67 & 390 & 55 & 26 \\
3 & 0.54 & 71 & 55 & 471 & 44 & 11 \\
4 & 0.39 & 96 & 89 & 428 & 74 & 31 \\
5 & 0.53 & 111 & 118 & 437 & 70 & 53 \\
6 & 0.43 & 52 & 88 & 520 & 74 & 26 \\
7 & 0.79 & 65 & 87 & 453 & 169 & 21 \\
8 & 0.33 & 73 & 143 & 610 & 79 & 87 \\
\hline
\end{tabular}

歳までの若年者である(Table 1).8 例すべてに麻疮 に定型的な皮疹と抗麻疹ウイルス抗体価の上昇を認め たことより麻疹と診断した。発熱の期間は平均 8.5 日 間，皮疹出現の期間は平均 5 日間であった。経過中の

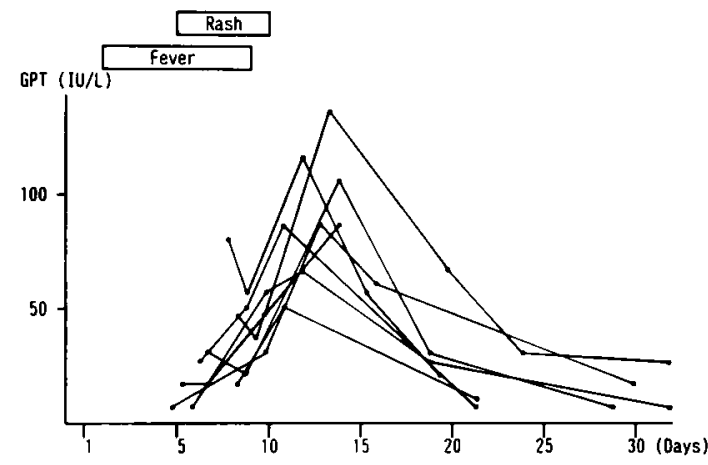

Fig. 1 Changes of serum GPT levels in 8 patients. GPT levels culminated to the maximal values in 6 -7 days and returned to normal within 4 weeks.

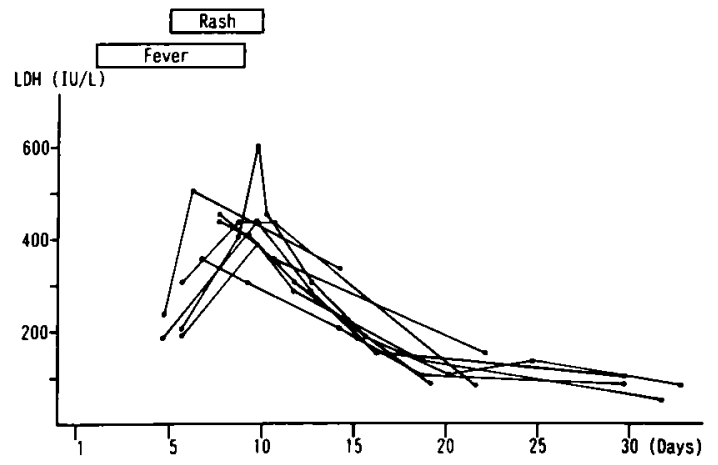

Fig. 2 Changes of serum LDH levels in 8 patients. Serum $\mathrm{LDH}$ levels culminated to maximal values on day $4-5$ and returned to normal within 3 weeks.
主な肝機能検查の最高值をみると, 血清 GOTは 52 111IU, GPT は55 143IU, LDH は349 610IU と 全例に上昇をみとめたが，いずれる軽度であり，黄疾 を認めた例はなかったＡ－Pの異常を示した例， $\gamma$ GTPの異常を示した例は，それぞれ1例ずつであり， 他は正常範团であった(Table 2).8 例の血清 GPTの 経過を示す(Fig. 1)，GPT は発疹出現時より上昇がみ られ, 発疮出現後 $6-7$ 日目に最高値を示し, 全例 1 カ月以内に正常となった。同様に，血清 LDH は発疹出 現時より上昇がみられ，発疹出現後 4 - 5 日目に最高 値を示し, 全例 3 週間以内に正常となった (Fig. 2). 血清 LDH は血清 GPT 值より 2 日ないし 3 日早く最 高値をとる傾向がみられた，血清 Al-P の経過は Fig. 3 のよ5に 8 例中 4 例で一過性の低下を認め, 特に症 例 7 でその傾向が顕著であった。他の症例では著明な 変化らみられなかった。一過性に Al-P の低下を認め た 4 例の平均年齢は 17.0 歳 (15 21歳)，一過性に上昇 した 3 例の平均年龄は 22.3 藏 $(21-23$ 藏)であり, Al-P の低下は比較的若い年代でみられた。血清 LDH と

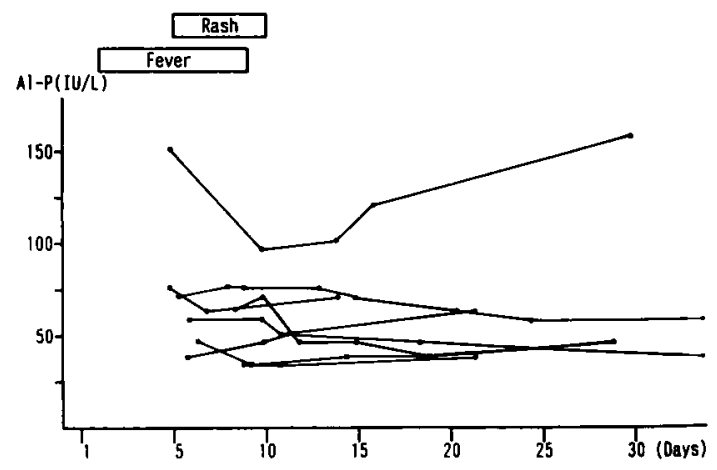

Fig. 3 Changes of serum alkaline phosphatase levels in 8 patients. Transient decrease was observed in 4 of 8 patients. 
Table 3 Histological findings of the liver.

\begin{tabular}{l|c|c|c|c|c|c}
\hline & Case 1 & Case 2 & Case 3 & Case 4 & Case 5 & Case 8 \\
\hline eosinophilic degeneration & - & - & + & + & + & + \\
focal necrosis & + & + & + & + & + & + \\
nuclear vacuolation & + & + & + & - & - & + \\
liver cell pleomorphysm & + & + & + & + & + & + \\
cellular infiltration to sinusoid & + & + & + & + & + & + \\
wall thickness of central vein & + & - & + & - & + & + \\
Kupffer cell proliferation & + & + & + & + & + & + \\
edema and cellular infiltration of portal tract & + & + & - & + & + & - \\
bile ductular proliferation & - & - & - & - & - & - \\
fibrosis & - & - & - & - & - & - \\
\hline
\end{tabular}

- : negative, $+:$ mild, + : moderate

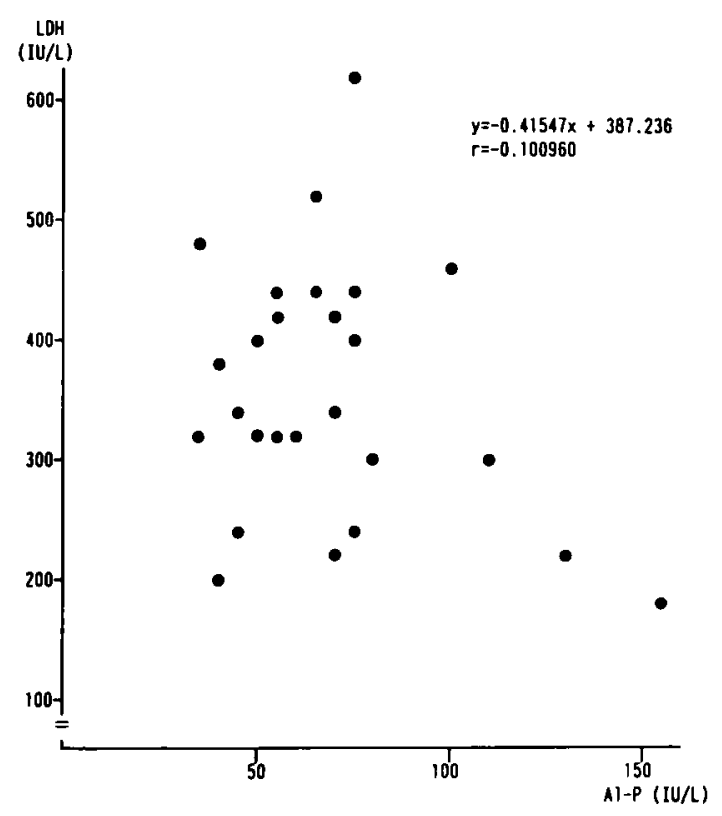

Fig. 4 Relationship between serum lactate dehydrogenase and alkaline phosphatase. There is no statistical significant correlation between them.

Al-Pは, 負の相関の傾向がみられたが，統計学的には 有意ではなかった (Fig. 4)，8例中 6 例に肝生検が施 行された。組織学的所見では，全例に肝実質の巣状壊 死、肝細胞の大小不同がみられた。星細胞の増殖も全 例でみられたか，小葉中心部 (zone 1) と辺縁部 (zone 3)て程度の差を認めなかった。クリンン䩗 (グ䩗) 域 では軽度の細胞浸潤を認めたが, 線維化はみられな かった。また，6 例中 4 例に多数の空胞核を認めたが， 麻疹ウイルスの封入体は認めなかった（Table 3)
(Fig. 5).

次に, 詳細な臨床経過を追跡し得た症例 2 について 報告する.

患者：21墄，女性.

主訴：発熱，咳濑。

家族歴：一卵性双生児の姉（症例 1）か麻疹に罹患，

4 月9日より発熱, 4月13日より発疹が出現している. 既往歴：特記事項なし。

現病歴：平成 3 年 4 月21日より発熱があり，23日に 当科を受診した。来院時 $\mathrm{WBC} 5,700 / \mathrm{mm}^{3}$, 発疹もな く自宅で経過観察していたが， $39^{\circ} \mathrm{Cを}$ 越える弛張熱が 持続した，24日より咳濑がみられ，25日に発疹が出現 したため当科を再受診し，麻疹が疑われ入院となった。 入院時現症：身長 $154 \mathrm{~cm}$, 体重 $46 \mathrm{~kg}$, 脈拍 $90 /$ 分, 整, 血圧 $100 / 58 \mathrm{mmHg}$, 体温 $40.5^{\circ} \mathrm{C}$, 結膜に董血, 黄庭を 認めず，表在リンバ節も触知しなかった。顔面に小丘 疹状の発疹を認めたが,コプリック斑は認めなかった。 胸、腹部に異常所見なく、神経学的所見にも異常を認 めなかった。入院時検查所見では, WBC $6.500 / \mathrm{mm}^{3}$, GOT, GPT, Al-P は正常域で, LDH の軽度の上昇を 認めた(Table 4). 発疹出現後 GOT, GPT, LDH の 上昇を認め。 LDH は第 10 病日に, GOT, GPT は第 12 病日にそれぞれ最高値を示し，約10日間で正常となっ た. IgM 分画の麻疹抗体は第 3 病日には陰性であった が、第10病日には陽性となった. LDH フインザイムは 第 6 病日にはLDH2, LDH3の上昇を認めたが，第12病 日にはLDH4，LDH5が上昇していた（Fig. 6)。第12 病日にェコーガイド肝生検を行った（Fig. 7)，肝細 胞の大小不同, 单状壊死, 類洞内への細胞浸潤も欢 れ，急性肝炎回復期の像と診断した。 


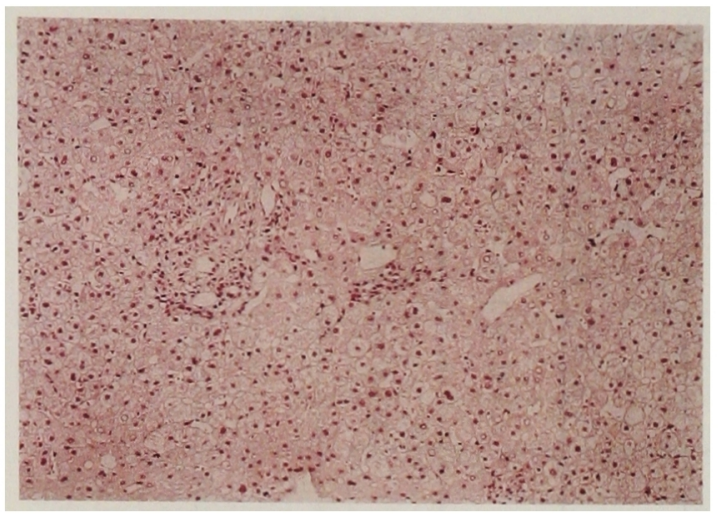

Fig. 5 Light microscopy revealed nuclear vacuolation in the sinusoid and focal hepatic cell necrosis in the liver parenchyma.

Table 4 Laboratory findings on admission.

\begin{tabular}{|c|c|c|c|}
\hline \multicolumn{2}{|c|}{ Peripheral blood } & MB & $3 \%$ \\
\hline $\mathrm{WBC}$ & $6.500 \mathrm{~mm}^{3}$ & MM & $96 \%$ \\
\hline $\mathrm{RBC}$ & $509 \times 10^{4} \mathrm{~mm}^{3}$ & \multicolumn{2}{|c|}{ Myosin light chain } \\
\hline $\mathrm{Hb}$ & $15.8 \mathrm{~g} \mathrm{~d} l$ & \multicolumn{2}{|c|}{$<2.5 \mathrm{ng} / \mathrm{m} l$} \\
\hline $\mathrm{Ht}$ & $44.4 \%$ & Myoglobin & $31 \mathrm{ng} / \mathrm{m} l$ \\
\hline PLT & $13.6 \times 10^{4} / \mathrm{mm}^{3}$ & $\mathrm{Na}$ & $146 \mathrm{mEq} / \mathrm{L}$ \\
\hline \multicolumn{2}{|c|}{ Blood chemistry } & $\mathrm{K}$ & $3.2 \mathrm{mEq} / \mathrm{L}$ \\
\hline $\mathrm{TP}$ & $7.5 \mathrm{~g} / \mathrm{d} l$ & $\mathrm{Cl}$ & $104 \mathrm{mEq} / \mathrm{L}$ \\
\hline Alb & $4.0 \mathrm{~g} / \mathrm{d} l$ & Serology & \\
\hline $\mathrm{T} \cdot \mathrm{Bil}$ & $0.49 \mathrm{mg} \mathrm{d} l$ & CRP & $1.0 \mathrm{mg} / \mathrm{d} l$ \\
\hline TTT & $8.6 u$ & ESR & $25 \mathrm{~mm} / \mathrm{hr}$ \\
\hline ZTT & $2.9 \mathrm{u}$ & \multicolumn{2}{|l|}{ Immunoglobulin } \\
\hline GOT & $28 \mathrm{II}^{\circ} \mathrm{L}$ & IgG & $1.557 \mathrm{mg} / \mathrm{d} l$ \\
\hline GPT & $4 \mathrm{IU} / \mathrm{L}$ & IgA & $335 \mathrm{mg} / \mathrm{d} /$ \\
\hline $\mathrm{LDH}$ & $202 \mathrm{IU} / \mathrm{L}$ & $\mathrm{IgM}$ & $415 \mathrm{mg} / \mathrm{d} l$ \\
\hline LDH1 & $29.4 \%$ & \multicolumn{2}{|c|}{ Viral antibody titer } \\
\hline $\mathrm{LDH} 2$ & $35.8 \%$ & Measles & \\
\hline LDH3 & $23.9 \%$ & $\operatorname{Ig} M \cdot E I A$ & $(-)$ \\
\hline $\mathrm{LDH} 4$ & $6.6 \%$ & $\operatorname{IgG}(E I A)$ & $(-)$ \\
\hline LDH5 & $4.3 \%$ & Rubella & \\
\hline LAP & $119 u$. & $\operatorname{IgM}(E I A)$ & $(-)$ \\
\hline ALP & $42 \mathrm{IU} / \mathrm{L}$ & $\operatorname{IgG}(\mathrm{EIA})$ & $(-)$ \\
\hline$\gamma$-GTP & $9 \mathrm{IU} / \mathrm{L}$ & EB. VCA & \\
\hline AMY & $151 \mathrm{IU} / \mathrm{L}$ & $\operatorname{IgM}(F A)$ & $<\times 10$ \\
\hline CPK & $1,153 \mathrm{IU} / \mathrm{L}$ & $\mathrm{CMV}$ & \\
\hline BB & $1 \%$ & $\operatorname{Ig} M(F A)$ & $<\times 4$ \\
\hline
\end{tabular}

\section{考察}

麻疹に伴 5肝障害は比較的稀とされていたが，最近 本邦でも小児例を中心にいくつかの報告がみられる。 麻疹に伴 5 肝機能娭査值の異常の原因を肝病変以外に 求める報告もみられ，異常を示す機序については不明

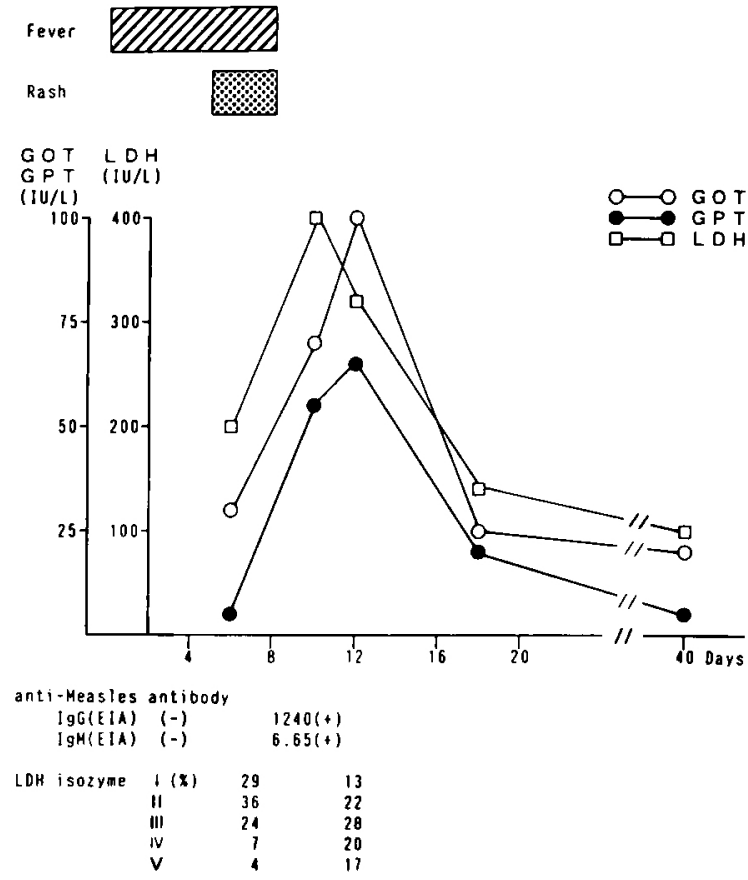

Fig. 6 Clinical course of case 2

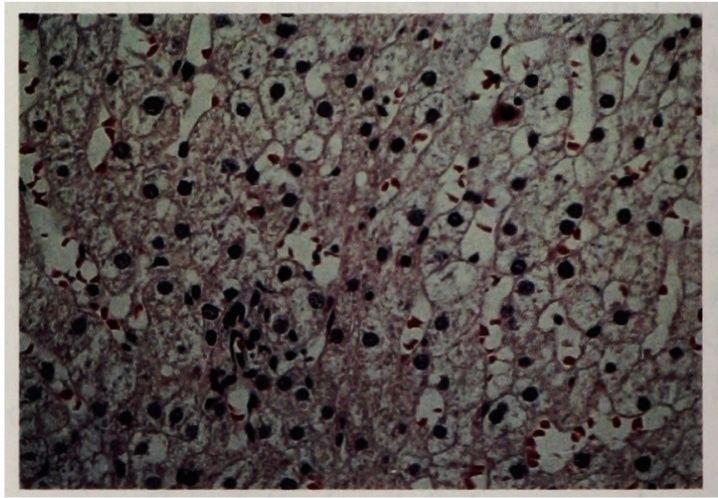

Fig. 7 Histological findings of the lever. Inflam. matory cells infiltration and focal necrosis were observed in the liver parenchyma.

な点も多い、そこで著者らは，1988年以降入院を要し た成人発症の麻疹患者 8 例の肝病変について臨床病理 学的に検討した。

8 例はいずれも高熱，全身倦急感，食欲不振のため 入院を必要とし，全例に肝機能異常を認めた，麻疹の 合併症としての肝障害は欧米ではいくつかの報告がみ られるが，本邦での報告は比較的少なく，臨床的には 注目されていないようである，肝機能異常を認める頻 
度については一定の見解は得られておらず，報告者に よりさまざすである. Leiboviciら゙は461人の成人麻 疹患者のらち51\%に肝逸脱醉素の上昇を認めたと報告 している，Gavish ら”は成人麻疹の入院患者 65 人中 $80 \%$ に, Mouallem Б $5^{21}$ は軍人の麻疹患者 40 人中 $70 \%$

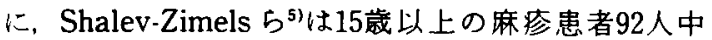
$66 \%$ に肝機能異常を認めたと報告している.本邦では，

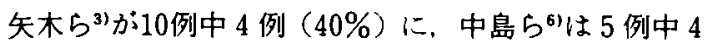
例（80\%）に肝機能異常を認めたと報告している，麻 疹に伴 5月機能異常の頻度は，決して稀なものではな く，報告者により肝障害の出現頻度に差が認められる 要因として，麻疹患者のうち肝機能検查の施行された 例のみを対象としたり，入院例のみを対象とするなと， 症例の選択方法に相違がみられることに起因すると考 えられる。 また，特定の地区で肝障害を示す例が高頻 度であったとの報告むあり，これらの報告は，肝と強 い親和性を示す麻疹ウイルスの存在を示唆してい $3^{31}$.

麻疹に伴 5 肝機能障害の程度について，矢木ら ${ }^{31}$ は， GOT 308 438IU, GPT 205 293IU, LDH 772 953 IU と GOT, GPT の著明な上昇を認めた 2 例の成人麻 疹例を報告している。蓑た，Gavish ら"の報告例のら ち肝機能異常を示した52例中にも GOT 900IU, GPT 736IU，LDH 437IU と GOT，GPT の著明に上昇した 例を含め, GOT, GPT ともに400IU 以上でかっ LDH に比べOT, GPT か優位に上昇している例が 4 例見 られる。

肝障害のほとんどは， $1 ー 3$ 週間で正常化するが， 数週間にわたり遷延する例の報告るみられる14.

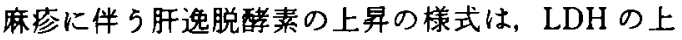
昇に比ベトランスフミナーゼの上昇は軽度とする報告 が多い，中鳦ら》は入院した麻疹患者76例の LDHは

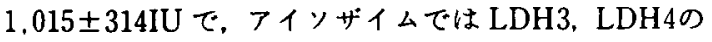

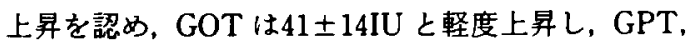
CPK は正常範囲であったことから LDHの上昇は肺 炎, 心筋障害, 肝障害などによるわのではなく，麻疹 特有のすのであるとしている．菅谷ら゙1は 8 名中の麻 疮患児について, 血清 LDH は LDH3を中心に平均 $1,184 \pm 135 \mathrm{IU}$ と著明に上昇していたが，GOTは平均 $61.3 \pm 4.2 \mathrm{IU}$ とごく軽度の上昇にとどまり，GPT， LDH5，Al-P等は正常であったとしている。これらの 事実より，菅谷らは，血清 LDH の由来については，麻 疹ウイルスに感染したリン八球の破壊によりLDH3 を中心としたリンバ球内の LDH が血清中に放出され
たものと推測している，木村ら豆はGOT，GPT > 100 $\mathrm{IU}$, かつ GOT<GPT の群を肝機能異常と考え, その 他の場合は必ずしも肝由来とは限らないと述べてい る. 自験例では, GOT は52〜111IU, GPT は55〜143 IU, LDH は349 610IU といずれも軽度の上昇であっ たが、組織学的に肝細胞壊死の所見を全例に認めたこ とより，肝機能異常の原因は肝細胞壊死に由来するる のと考えられた。

逸脱醅素の経時的变動についてみると, 血清 GPT 值は発疹の出現とと。に上昇し, 発疹出現後 $6 \sim 7$ 日 に最高值をとり, 以後経過とともに正常化した，血清 LDH は発疹出現時より上昇し, GPT 上り $2 \sim 3$ 日早 く最高値をとる傾向がみられ, 出現後 4 - 5 日で最高 となり，発疹出現後約 2 週間で正常化した. LDH アイ ソザイムについては，アインザイムを測定しえた 1 例 では, 発疹出現時には LDH2, LDH3が上昇していた が, GPT, LDH が極値に達する頃には LDH4, LDH5 の上昇がみられた，以上より，逸脱䤃素の推移から病 期を推測することが可能であった。なお，GPT，LDH の值と臨床症状の重症度には相関はみられなかった。

麻济患者における訮生模組織所見についての報告は 少ない. Modai ら"1は, 肝酵素がビークに達した時期 に肝生検を行った 3 例について, 白血球浸潤を伴った 空胞核が散見されたが，門脈域には著変を認めなかっ たと報告している。外山ら ${ }^{221}$ は, 麻疹患者 2 例に肝生検 を行ったが, 肝細胞の配列の乱れとク䩗域への軽度の リンバ球浸潤を認めるのみで，特異的な肝組織像は見 られなかったとしている。塩崎ら ${ }^{131}$ は，1例に肝生検を 行ったが，組織像は肝細胞の腫大と門脈域への軽度の 細胞浸潤を認めるだけであったと報告している. Moench 5 ${ }^{15)}$ は，麻疹で死亡した20例中, 皮疹出現後 5 日以内に死亡した 9 例のうち 5 例で, 種々の葴器にお いて免度組織化学的にウイルス抗原の存在を示し，ら ち 1 例においては胆管上皮に認めている。われわれの 症例では， 8 例中 6 例で肝生検が行われ，組織学的所 見ではいずれもリンバ球浸潤を伴う点状一巣状の肝細 胞壊死がみられ、トランスフミナーゼの上昇は肝細胞 壊死に基つくるのと考えられた。充た 6 例中 4 例に多 数の空胞核を認めており，麻疹に伴ら変化として興味 ある所見と考えられた。

本邦でも成人麻疹例の報告は年々増加しており，麻 疹患者については，入院を要するよらな重症例のみな らす軽症例においても肝機能検查を施行し，麻疹を伴 万肝病変についてさらに詳細な検討が必要と考えた。 
矢木ら33は，ある地域でのきわめて高頻度な肝機能異 常を報告し，肝親和性麻疹ウイルス株の可能性を指摘 しておりこの点についても今後遺伝子レベルでの検 討が必要であると考えられた。

\section{文嗝}

1) Gavish D, Kleinman Y, Morag A, et al : Hepatitis and jaundice associated with measles in young adults. Arth Intern Med 143: 674-677, 1983

2) Mouallem M, Friedman E, Pauzner R, et al: Measles epidemic in young adults. Arch Intern Med 147: 1111-1113, 1987

3）矢木文和，右見正夫，佐藤 登，他：肝障害を合併 した麻疹の 4 症例。臨床と研究 63 ：517-519， 1986

4) Leibovici L, Sharir T, Kalter-Leibovici O, et al : An outbreak of measles among young adults. J Adolescent Health Care $9:$ 203-207, 1988

5) Shalev-Zimels $\mathrm{H}$, Weizman $Z$, Lotan $\mathrm{C}$, et al : Extent of measles hepatitis in various ages. Hepatology 8: 1138-1139, 1988

6）中島倫子，山田信夫，中島壮太：麻疹の合併症とし ての肝炎一その 4 症例。臨床之研究 65：511 $-514,1988$

7) 中鴆敏宏，四方宅磨，高永，他：麻疹に打ける 血清 $L D H$ 上昇について。南大阪医学 35：111
$-117,1991$

8）菅谷憲夫, 菲沢真理, 三田村敬子，他：麻疹に捕け る血清醉素の上年。日児誌 $92: 229-233,1988$

9）木村正彦，稲垣真澄，中島雅子，他：麻疹における 血清 GOT，GPT，LDH，CPK 值について。 小児 科臨床 $42: 1964-1968,1989$

10）有田耕司, 福島章子, 外川正生：麻疹患児の肝機能 唉査値について。少科臨床 $41: 884-888,1988$

11) Modai D, Pik A, Marmor $Z$, et al: Liver dysfunction in measles, liver biopsy findings. Dig Dis Scien $31: 333,1986$

12）外山久太郎，三富弘之，安達 献，他：成人におけ る麻疹ウイルス感染に上る肝炎の 2 例。内科 59 : $779-782,1987$

13）塩崎裕士，森下鉄夫，阿部㭲和，他：成人発症の麻 参に合併した肝障害の 2 例，静岡赤十字病院研究 報 $8: 56$-59, 1988

14) Levo $Y, W o l l n e r ~ S$, Shalit $M$ : Serum amyloid P-Component as a marker of liver involvement in measles infection. Am J Gastroent 80:391 $-392,1985$

15) Moench $T R$, Griffin $\mathrm{DE}$, Obriecht $\mathrm{CR}$, et al : Acute measles in patient with and without neurological involvement: Distribution of measles virus antigen and RNA. J Infect Dis $158: 433-442,1988$ 


\title{
Clinicopathological study on liver injury in young adult patients with measles
}

\author{
Yasuo NIKI, Mitsukazu MryazaKI, Ryoichi Ishisu, Ayumu NaKanishi, Yukiro MaKino, \\ Atsuya Shimizu, Yukinobu Noguchi, Shinsei Tagawa, Samon Murata*, \\ Nobuyasu Ito, Kojiro TaKase, Takeshi NaKano**, \\ Yukihiko TAMEDA and Yoshitane KoSAKA***
}

Eight young adult patient (15-23 yr) were studied. They were the patients who required hospitalization among patients having suffered from measles at the young adult age and visited our hospital in 1988 and thereafter. All of the patients showed a slight elevation of GOT, GPT and LDH but no jaundice. Serum GPT level increased with development of rash, reached maximum 6 to 7 days after their appearance, and then returned gradually to the normal level. Serum LDH increased at the time of appearance of rash, reached maximum 4 to 5 days after their appearance (i.e. 2 to 3 days earlier than the peak of GPT), and returned to normal about 2 weeks after onset of rash. Serum Al-P decreased transiently in 4 of the 8 patients. In the recovery stage, liver biopsy was madein 6 of the 8 patients. Histological examination showed slight necrosis of liver cells in all patients but no significant changes in portal area.

* Department of Internal Medicine, Shima Prefectural Hospital (Mie)

** First Department of Internal Medicine, Mie University School of Medicine (Mie)

*** Department of Laboratory Medicine, Mie University School of Medicine (Mie) 